\title{
DEGRADASI FISIK BETON NORMAL PASCA BAKAR
}

\author{
Fauzan Hamdi ${ }^{1)}$. Muh. Syafaat S. Kuba ${ }^{2)}$ \\ ${ }^{1)}$ Prodi Teknik Sipil Pengairan, Fakultas Teknik, Universitas Muhammadiyah Makassar \\ Jl. Sultan Alauddin No.259 Makassar 90221, Telp: (0411) 866972 \\ Email: fauzanhamdiunismuh@gmail.com \\ ${ }^{2)}$ Prodi Teknik Sipil Pengairan, Fakultas Teknik, Universitas Muhammadiyah Makassar \\ J1. Sultan Alauddin No.259 Makassar 90221, Telp: (0411) 866972 \\ Email: syafaat_skuba@ rocketmail.com
}

\begin{abstract}
A research about the effect of semen's temperature is still being a hot topic to be investigated. The effect of temperature need to be measured, physically or mechanically, and also need to be analyzed by using descriptive statistic analysis. The researchers' expectation in knowing a formulation, a description, and a big effect of temperature to semen is something which still need to be discussed more. The researchers begin to investigate it by making a tool of semen's test which fired in an oven directly. The tool of semen's test next to be tested its pressure power, elastic power, and elastic modules. The research had been done to fired building so far, but the result still not give a basic power. Generally, the problem of this research is to know semen's normal degradation physically and mechanically after firing in certain temperature. The result showed that there was a physic degradation happened to semen after firing. The height of normal semen after firing was $0,002331 \mathrm{~kg} / \mathrm{cm} 3$ in normal temperature, $0,002259 \mathrm{~kg} / \mathrm{cm} 3$ in $100^{\circ} \mathrm{C}$ temperature, 0,002203 in $300^{\circ} \mathrm{C}$ temperature, and $0,002182 \mathrm{~kg} / \mathrm{cm} 3$ in $600^{\circ} \mathrm{C}$ temperature.
\end{abstract}

Keywords: Normal Concrette, Physic, Burn

\begin{abstract}
Abstrak
Penelitian tentang pengaruh temperatur pada beton masih merupakan topik yang hangat diteliti. Pengaruh temperatur diukur, baik sifat fisik maupun sifat mekanik, dan dianalisis dengan menggunakan analisis statistik deskriptif. Keinginan para peneliti untuk mengetahui secara akurat bentuk, gambaran, dan besar pengaruh temperatur terhadap beton merupakan hal yang masih perlu diteliti lebih lanjut. Para peneliti mulai meneliti dengan membuat benda uji beton yang kemudian dibakar langsung dibakar dalam oven atau tungku. Setelah itu, dilakukan pengujian pada benda uji berupa kuat tekan, kuat lentur, dan modulus elastisitas. Penelitian yang pernah dilakukan adalah sisa suatu bangunan yang telah terbakar. Namun sejauh ini penelitian penaksiran tersebut masih belum menemukan landasan awal yang kuat. Secara garis besar masalah yang diteliti dalam penelitian ini adalah peneliti ingin mengetahui besar degradasi beton normal secara fisik dan mekanik setelah dibakar pada suhu tertentu dan dibandingkan dengan beton normal yang tidak dibakar. Hasil ini diharapkan dapat memberikan dasar bagi penanggulangan bangunan yang telah terbakar. Hasil yang dicapai yaitu beton normal terjadi degradasi fisik akibat pasca bakar. Hasilnya yaitu berat isi rata-rata beton normal pasca bakar yaitu pada suhu normal sebesar $0,002331 \mathrm{~kg} / \mathrm{cm} 3$, suhu $100^{\circ} \mathrm{C}$ sebesar $0,002259 \mathrm{~kg} / \mathrm{cm} 3$, suhu $300^{\circ} \mathrm{C}$ sebesar 0,002203 $\mathrm{kg} / \mathrm{cm} 3$, suhu $600^{\circ} \mathrm{C}$ sebesar $0,002182 \mathrm{~kg} / \mathrm{cm} 3$.
\end{abstract}

Kata Kunci: Beton Normal, Fisik, Bakar

\section{PENDAHULUAN}

\section{Latar Belakang}

Salah satu tantangan yang dihadapi para ahli struktur (teknik sipil) adalah bagaimana menganalisis kekuatan struktur beton pada gedung akibat:

1. Temperatur tertinggi yang dialami elemen bangunan pada saat kebakaran

2. Kekuatan sisa bangunan pasca kebakaran

3. Teknik perkuatan bangunan sesuai keperluan sehingga fungsi bangunan dapat dikembalikan seperti sebelum terjadi kebakaran.

Untuk menjawab secara ilmiah tantangan tersebut sekaligus membantu masyarakat dalam menangani masalah ini secara tepat, telah dikembangkan berbagai metode penaksiran, baik secara non-destruktif maupun secara destruktif. Metode ini digunakan untuk dapat secara akurat temperature tertinggi yang pernah dialami bangunan, kekuatan sisa struktur bangunan pasca kebakaran, dan teknik perkuatan bangunannya. Berbagai masalah teknik yang menyangkut penaksiran kekuatan sisa dan teknik perkuatan elemen struktur tersebut hasilnya dimanfaatkan oleh pihak lain yang terkait, seperti bank, pemilik bangunan, kepolisian, pengacara hukum, dan perusahaan asuransi. Berikut ini dapat kita lihat pada gambar 1 terjadinya kerusakan gedung pasca kebakaran.

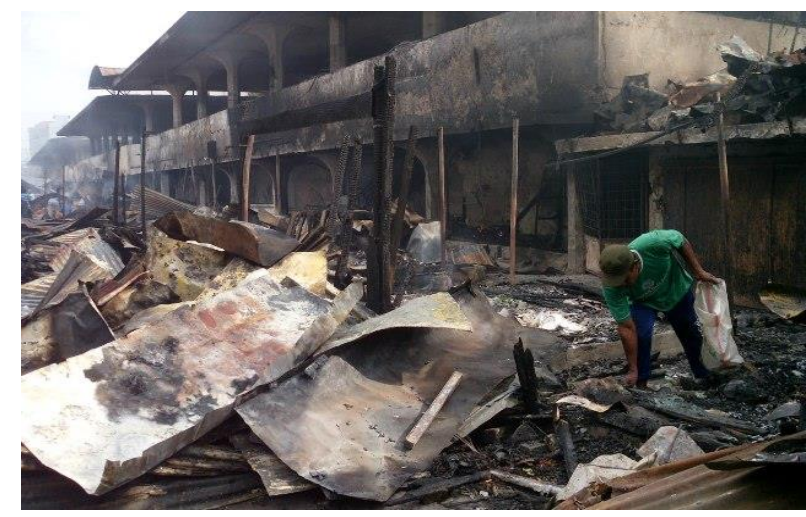

Sumber:

http://www.solopos.com/2015/05/14/pasar-joharterbakar-anggaran-pembangunan-pasar-daruratturun-jadi-rp215-miliar-60428 


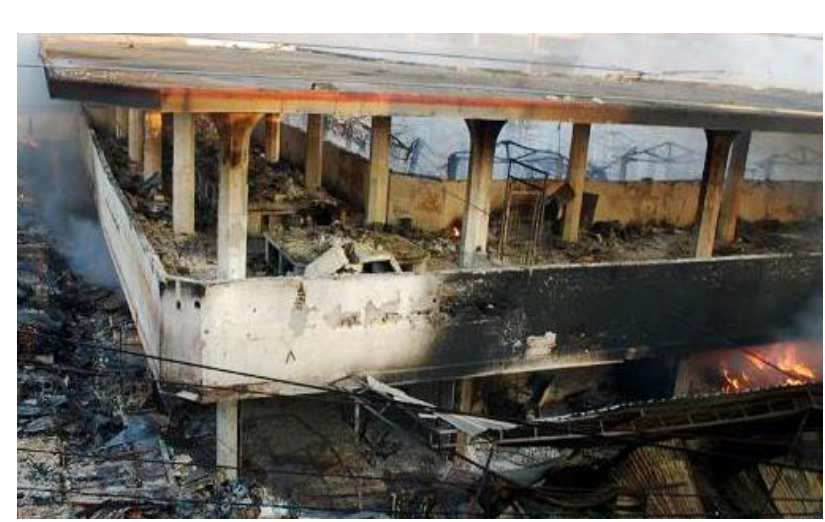

Sumber:

https://www.radioidola.com/tag/revitalisasi-pasarjoharl

Gambar 1. Gedung pasca kebakaran

Sampai saat ini penelitian tentang pengaruh temperatur pada beton masih merupakan topik yang hangat diteliti. Pengaruh temperatur diukur sifat fisik dan dianalisis dengan menggunakan analisis statistik deskriptif. Keinginan para peneliti untuk mengetahui secara akurat bentuk, gambaran, dan besar pengaruh temperatur terhadap beton merupakan hal yang masih perlu diteliti lebih lanjut. Para peneliti mulai meneliti dengan membuat benda uji beton yang kemudian dibakar langsung atau dibakar dalam oven atau tungku. Setelah itu, dilakukan pengujian pada benda uji berupa kuat tekan, kuat lentur, dan modulus elastisitas. Penelitian yang pernah dilakukan adalah sisa suatu bangunan yang telah terbakar. Namun sejauh ini penelitian penaksiran tersebut masih belum menemukan landasan awal yang kuat.

Secara garis besar masalah yang diteliti dalam penelitian ini adalah peneliti ingin mengetahui besar degradasi beton normal secara fisik setelah dibakar pada suhu tertentu dan dibandingkan dengan beton normal yang tidak dibakar. Hasil ini diharapkan dapat memberikan dasar bagi penanggulangan bangunan yang telah terbakar.

\section{Rumusan Masalah}

Dengan memperhatikan berbagai permasalahan yang diakibatkan oleh struktur bangunan beton yang mengalami kebakaran baik secara sosial, material, finansial, dan berbagai masalah yang lainnya merupakan suatu hal yang perlu mendapatkan perhatian dan solusi dalam menyelesaikan permasalahan tersebut. Sehingga perlu menjadi perhatian khusus dalam penyelesaiannya. Salah satu cara mengatasi masalah tersebut, peneliti mengambil bagian yang bisa membatu dalam penyelesaian berupa mengetahui degradasi beton secara fisik akibat pasca kebakaran.

\section{TUJUAN DAN MANFAAT PENELITIAN \\ Tujuan Penelitian}

Tujuan dari penelitian ini adalah untuk mengetahui besar degradasi beton normal akibat pasca bakar baik secara fisik.

\section{Manfaat Penelitian}

1. Dapat dijadikan rujukan dalam mengembangkan ilmu pengetahuan dalam bidang sains bangunan pada umumnya dan bidang kenyamanan termal pada khususnya.

2. Memberi kontribusi dalam mengatasi permasalahan yang diakibatkan oleh struktur bangunan beton yang mengalami kebakaran, baik berupa kekuatan fisik beton akibat kebakaran.

\section{TINJAUAN PUSTAKA \\ Pengertian Beton}

Beton terdiri atas agregat, semen dan air yang dicampur bersama-sama dalam keadaan plastis dan mudah untuk dikerjakan. Karena sifat ini menyebabkan beton mudah untuk dibentuk sesuai dengan keinginan pengguna. Pada saat pencampuran telah selesai, adukan terjadi reaksi kimia yang umumnya bersifat hidrasi dan menghasilkan suatu pengerasan dan pertambahan kekuatan.

Mulyono (2006), mengungkapkan bahwa beton merupakan fungsi dari bahan penyusunnya yang terdiri dari bahan semen hidrolik, agregat kasar, agregat halus, air, dan bahan tambah. Sedang Sagel dkk. (1994), menguraikan bahwa beton adalah suatu komposit dari bahan batuan yang direkatkan oleh bahan ikat. Sifat beton dipengaruhi oleh bahan pembentuknya serta cara pengerjaannya. Semen mempengaruhi kecepatan pengerasan beton. Selanjutnya kadar lumpur, kebersihan, dan gradasi agregat mempengaruhi kekuatan pengerjaan yang mencakup cara penuangan, pemadatan, dan perawatan, yang pada akhirnya mempengaruhi kekuatan beton.

Kekuatan beton terutama dipengaruhi oleh banyaknya air dan semen yang digunakan atau tergantung pada faktor air semen dan derajat kekompakannya. Adapun factor yang mempengaruhi kekuatan beton adalah perbandingan berat air dan semen, tipe dan gradasi agregat, kualitas semen, dan perawatan (curing).

\section{Sifat Beton Pasca Bakar}

Penelitian yang dilakukan oleh Sirait (2009), menggunakan balok beton bertulang penampang empat persegi ukuran $15 \times 25 \times 320$, terletak pada tumpuan sederhana, bertulangan lemah. Waktu pembakaran mulai dari 30, 60, 90 dan 120 menit dengan balok yang berbeda pada suhu $500^{\circ} \mathrm{C}$ sejak awal hingga akhir pembakaran dan tanpa pembebanan. Pembebanan pada uji lentur menunjukkan penurunan daya pikul sebesar $26 \%$, demikian juga pada uji kuat tekan beton menunjukkan penurunan kuat tekan beton sebesar $65 \%$ dari kekuatan awal.

Adapun hasil penelitian Ahmad dan Taufieq (2006), menyatakan bahwa terjadi penurunan kekuatan pada bangunan beton yang telah dioven. Pada penelitian ini didapatkan kuat tekan pada beton yang tidak dioven sebesar $240,0624 \mathrm{~kg} / \mathrm{cm} 2$. Kekuatan sisa beton yang dioven pada temperatur $200^{\circ} \mathrm{C}$ dan $400^{\circ} \mathrm{C}$ adalah $88,89 \%$ dan $70,15 \%$ dari kekuatan beton normal yang tidak dioven. 
Menurut Zacoeb dan Anggraini (2005), perubahan temperatur yang cukup tinggi, seperti yang terjadi pada peristiwa kebakaran, akan membawa dampak pada struktur beton. Karena pada proses tersebut akan terjadi suatu siklus pemanasan dan pendinginan yang bergantian, yang menyebabkan terjadinya perubahan fase fisis dan kimiawi secara kompleks. Hal ini akan mempengaruhi kualitas/kekuatan struktur beton tersebut. Pada beton normal mutu tinggi dengan suhu $1200^{\circ} \mathrm{C}$ terjadi penurunan kekuatan tekan sampai tinggal $40 \%$ dari kekuatan awal. Sedangkan pada beton mutu tinggi dengan Silikafume dan Superplasticizer akan mengalami perubahan yang cukup berarti pada suhu tinggi dimana kekuatannya tinggal $35 \%$.

Ahmad (2001), membahas kelayakan balok beton bertulang pascabakar secara analisis dan eksperimen. Penelitian dilakukan terhadap lima benda uji berbentuk balok beton bertulang. Empat balok dibakar di dalam tungku pada temperatur $200^{\circ} \mathrm{C}$ dan $400^{\circ} \mathrm{C}$ selama \pm 3 jam dan satu balok lain yang tidak dibakar sebagai pembanding. Hubungan tegangan regangan memperlihatkan perubahan kemiringan kurva atau dengan kata lain terjadi penurunan kekakuan sejalan dengan kenaikan temperatur dan diikuti dengan penambahan regangan maksimum.

Menurut Sumardi (2000), kebakaran pada hakekatnya merupakan reaksi kimia dari combustible material dengan oksigen yang dikenal dengan reaksi pembakaran yang menghasilkan panas. Panas hasil pembakaran ini diteruskan ke massa beton/mortar dengan dua macam mekanisme yakni pertama secara radiasi yaitu pancaran panas diterima oleh permukaan beton sehingga permukaan beton menjadi panas. Pancaran panas akan sangat potensial, jika suhu sumber panas relatif tinggi. Kedua secara konveksi yaitu udara panas yang bertiup/bersinggungan dengan permukaan beton/mortar sehingga beton menjadi panas. Bila tiupan angin semakin kencang, maka panas yang dipindahkan dengan cara konveksi semakin banyak.

Tjokrodimuljo (2000), mengatakan bahwa beton pada dasarnya tidak diharapkan mampu menahan panas sampai di atas $250^{\circ} \mathrm{C}$. Akibat panas, beton akan mengalami retak, terkelupas (spalling), dan kehilangan kekuatan. Kehilangan kekuatan terjadi karena perubahan komposisi kimia secara bertahap pada pasta semennya.

Selain hal tersebut di atas, panas juga menyebabkan beton berubah warna. Bila beton dipanasi sampai suhu sedikit di atas $300^{\circ} \mathrm{C}$, beton akan berubah warna menjadi merah muda. Jika di atas $600^{\circ} \mathrm{C}$, akan menjadi abu-abu agak hijau. Dengan demikian, secara kasar dapat diperkirakan berapa suhu tertinggi selama kebakaran berlangsung berdasarkan warna permukaan beton pada pemeriksaan pertama.

Rahmah (2000), menggunakan silinder hasil core case berdiameter $5 \mathrm{~cm}$ dari suatu model balok beton bertulang yang dibakar pada temperatur $200^{\circ} \mathrm{C}, 400^{\circ} \mathrm{C}$, $600^{\circ} \mathrm{C}$ dan $800^{\circ} \mathrm{C}$. Hasil dari penelitian ini adalah terjadi perubahan kuat tekan tiap sentimeter kedalaman core case beton sebesar $0,4 \%$; sedangkan perubahan modulus elastisitas tiap sentimeternya berkisar $1,2 \%-2,2 \%$.

\section{Kuat tekan beton}

Dalam SK SNI M-14-1989-E dijelaskan pengertian kuat tekan beton yakni besarnya beban per satuan luas yang menyebabkan benda uji beton hancur bila dibebani gaya tekan tertentu, yang dihasilkan oleh mesin tekan. Selanjutnya Mulyono (2006), mengemukakan bahwa kuat tekan beton mengidentifikasikan mutu sebuah struktur di mana semakintinggi tingkat kekuatan struktur yang dikehendaki, maka semakin tinggi pula mutu beton yang dihasilkan. Kekuatan tekan karakteristik $\sigma^{\prime}$ bk dihitung $\sigma^{\prime} \mathrm{bk}=\sigma^{\prime} \mathrm{bm}-1,64$ dengan taraf signifikan 5\%. Adapun faktor lain yang dapat mempengaruhi mutu kekuatan beton seperti yang dikemukakan oleh Mulyono (2006), yaitu:

1. Proporsi bahan penyusun

2. Metode pencampuran

3. Perawatan

4. Keadaan pada saat pengecoran.

\section{METODOLOGI PENELITIAN \\ Waktu dan Tempat Penelitian}

Penelitian ini dilaksanakan selama \pm 4 bulan yang berlangsung dari bulan Juli 2017 -Oktober 2017. Tempat penelitian dilaksanakan di Laboratorium Fakultas Teknik Universitas Muhammadiyah Makassar dan pembakaran beton dilakukan di tempat tungku pembakaran batubata di Kecamatan Bontonompo, Kabupaten Gowa, Provinsi Sulawesi Selatan.

\section{Bahan dan Alat}

Bahan beton yang digunakan dalam penelitian ini terdiri dari Semen Portland Composit yang didapatkan di kota Makassar, Sulawesi Selatan. Untuk agregat halus menggunakan pasir dari Sungai Je'ne'berang Kabupaten Gowa, Sulawesi Selatan dan agregat kasar berupa batu pecah yang digunakan yaitu dari hasil stone crusher di daerah Bili-Bili, Kabupaten Gowa, Sulawesi Selatan dan air PDAM yang dugunakan yang ada dikota Makassar Sulawesi Selatan. Adapun alat-alat yang digunakan untuk uji karakteristik material, mould untuk mal pembuatan benda uji, mixer concrete untuk mencampur adukan beton, slump test digunakan untuk mengukur kelecakan beton segar yaitu menggunakan alat-alat di Laboratorium Fakultas Teknik Universitas Muhammadiyah Makassar, tungku pembakaran sampel, alat pengukur suhu digital infrared thermometer $-50^{\circ} \mathrm{C} \sim 900^{\circ} \mathrm{C}$ dan mesin uji tekan beton.

\section{Metode Penelitian}

Bahan yang digunakan untuk penelitian harus disiapkan terlebih dahulu, ditentukan kualitas masingmasing bahan susunnya, serta dibuatkan cetakan untuk tempat benda uji yang telah direncanakan. Alat yang digunakan pada penelitian ini sebelumnya telah diperiksa kondisi dan kemampuannya serta telah dikalibrasi terlebih dahulu. Benda uji silinder dibuat dengan cara memasukkan beton segar dari molen ke dalam cetakan silinder ukuran $15 \mathrm{~cm}$ x $30 \mathrm{~cm}$ yang telah diolesi minyak pelumas. 
Pengisian ini dilakukan secara bertahap, yaitu tiap sepertiga bagian dilakukan penumbukan dengan tongkat baja sebanyak \pm 25 kali. Setelah 24 jam, cetakan dibuka kemudian dilakukan perawatan dengan direndam di dalam bak air selama 28 hari. Selanjutnya benda uji kemudian dibakar selama tiga jam pada temperatur $100^{\circ} \mathrm{C}, 300^{\circ} \mathrm{C}$ dan $600^{\circ} \mathrm{C}$, masing-masing sebanyak 5 buah dan 5 buah tidak dibakar, digunakakan sebagai benda uji pengontrol.

Data diperoleh melalui pengujian tekan di laboratorium dengan menggunakan mesin uji kuat tekan untuk semua benda uji. Hasil uji tekan beton berupa gaya (P) yang terjadi pada saat benda uji hancur. Berdasarkan data gaya tekan dan luas penampang silinder, maka kuat tekan beton dapat dihitung dengan menggunakan rumus:

$$
f=\frac{P}{A}
$$

dimana :

$\mathrm{f}=$ Kuat tekan $(\mathrm{kg} / \mathrm{cm} 2)$

$\mathrm{P}=$ Gaya tekan $(\mathrm{kg})$

$\mathrm{A}=$ Luas penampang kubus $(\mathrm{cm} 2)$

Untuk mengetahui rata-rata berat isi beton yang belum dibakar dan yang telah dibakar maka pengolahan data yang kami gunakan dalah denga cara analisis statistik.

\section{Bagan Alir Penelitian}

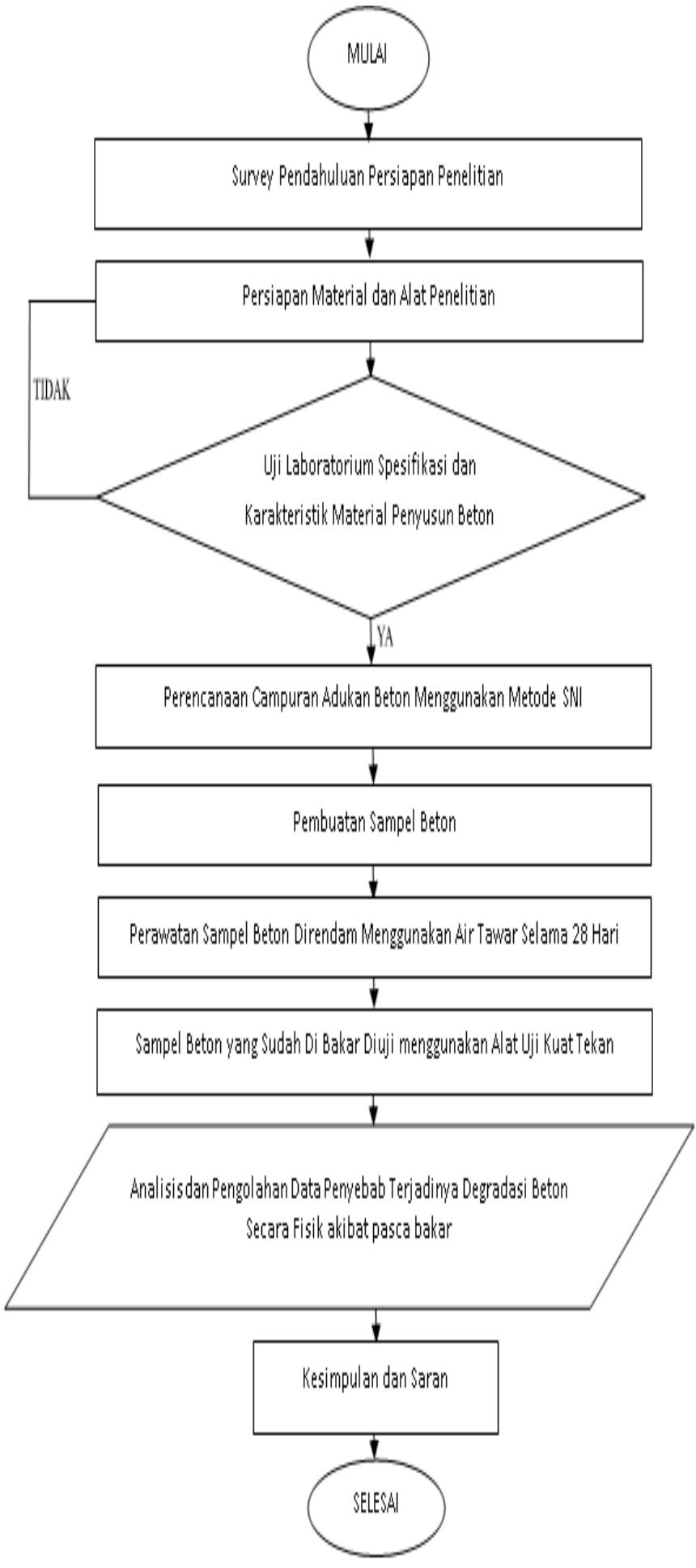

gambar 2. Bagan Alir Penelitian 


\section{ANALISA DAN HASIL}

\section{Karakteristik Material Penyusun Beton}

Semen penyusun beton menggunakan Portland Cement Composite (PCC) yang diperoleh dari pasar lokal di Makassar, Sulawesi Selatan.

Agregat penyusun beton terdiri dari agregat halus yang diperoleh dari Sungai Je'neberang, Kabupaten Gowa, Provinsi Sulawesi Selatan dan agregat kasar yang diperoleh dari Sungai Bili-Bili yang berbentuk batu pecah hasil pabrik "stone cruser" Kabupaten Gowa, Sulawesi Selatan.

Hasil pemeriksaan karakteristik agregat halus (pasir) menunjukkan bahwa memenuhi syarat spesifikasi SNI sehingga agregat halus dapat digunakan sebagai campuran beton. Hasil pemeriksaan tersebut dapat dilihat pada tabel 1 berikut:

Tabel 1. Hasil pemeriksaan karakteristik agregat halus (pasir)

\begin{tabular}{|c|c|c|c|c|c|}
\hline $\mathrm{NO}$ & $\begin{array}{l}\text { KARAKTERISTIK } \\
\text { AGREGATHALLS }\end{array}$ & Spesiffikasi SNI & INTERVAL & $\begin{array}{c}\text { HASIL } \\
\text { PEMERIKSAAN }\end{array}$ & KETERANGAN \\
\hline & Kadar lumpur & SNI 03-4141-1996 & $\operatorname{Maks} 5 \%$ & $1,25 \%$ & Memenuhi \\
\hline & Kadar organik & SNI 03-2816-1992 & $<\mathrm{NO} 0.3$ & $\mathrm{~N}_{0.1}$ & Memenuhi \\
\hline & Kadar air (Wp) & SNI 03-1971-1990 & $0,5 \%-5 \%$ & $1,60 \%$ & Memenuhi \\
\hline & Berat volume & SNI 03-4804-1998 & & & \\
\hline & a. Kondisilepas & & $1,4-1,9 \mathrm{~kg} / \mathrm{iter}$ & 1,42 & Memenuhi \\
\hline & b. Kondisipadat & & $1,4-1,9 \mathrm{~kg} / \mathrm{liter}$ & 1,65 & Memenuhi \\
\hline & Penverapan $(\mathrm{RP})$ & SNI 03-1970-1990 & $0,2 \% \cdot 2 \%$ & $1,42 \%$ & Memenuhi \\
\hline & $\begin{array}{l}\text { Berat jenis spesifik kering } \\
\text { perrmukaan }\end{array}$ & SNI 03-1970-1990 & $1,6 \cdot 3,3$ & $2,40 \%$ & Memenuhi \\
\hline & Modulus kehalusan & SNI 03-1968-1990 & $1,50-3,80$ & 3,46 & Memenuhi \\
\hline
\end{tabular}

Sumber: Hasil Laboratorium Teknik Sipil Universitas Muhammadiyah Makassar

Hasil pemeriksaan uji karakteristik agregat kasar (batu pecah) menunjukkan bahwa memenuhi syarat spesifikasi SNI sehingga agregat kasar dapat digunakan sebagai campuran beton. Hasil pemeriksaan tersebut dapat dilihat pada tabel 2 berikut:
Tabel 2. Hasil pemeriksaan karakteristik agregat kasar (batu pecah)

\begin{tabular}{|c|c|c|c|c|}
\hline \begin{tabular}{|l|l} 
N0 & KARAKTERISTIK \\
& AGREGAT KASAR \\
\end{tabular} & SpesifikasiSNI & INTERVAL & \begin{tabular}{|c|} 
HASIL \\
PEMERIKSAAN \\
\end{tabular} & KETERANGAN \\
\hline 1 Keausan & SNI03-2417-1991 & Maks 50\% & $20,38 \%$ & Memenuhi \\
\hline 2 Kadar umpur & SNI03-4141-1996 & Maks $1 \%$ & $0,90 \%$ & Memenuhi \\
\hline 3 Kadara air(Wk) & SNI03-1971-1990 & $0,5 \%-2 \%$ & $1,34 \%$ & Memenuhi \\
\hline 4 Berat volume & SNI03-4804-1998 & & & \\
\hline a. Kondisilepas & & $1,6-1,9 \mathrm{kgllit}$ ter & 1,61 & Memenuhi \\
\hline b. Kondisipadat & & $1,6-1,9 \mathrm{kglliter}$ & 1,66 & Memenuhi \\
\hline 5 Penyerapan (Rk) & SNI03-1969-1990 & Maks $4 \%$ & $2,78 \%$ & Memenuhi \\
\hline $6 \begin{array}{l}\text { Berat jenis spesiffik kering } \\
\text { permukaan }\end{array}$ & SNI03-1969-1990 & $1,6-3,3$ & 2,60 & Memenuhi \\
\hline 7 Modulus kehalusan & SNI03-1968-1990 & $6,0-7,1$ & 3,28 & Memenuhi \\
\hline
\end{tabular}

Sumber: Hasil Laboratorium Teknik Sipil Universitas Muhammadiyah Makassar

Dari hasil analisis perhitungan mix design menggunakan Metode Standar Nasional Indonesia (SNI) maka komposisi bahan campuran beton normal dengan mutu beton rencana $\left(f^{\prime} c\right)=25 \mathrm{MPa}$ menggunakan faktor air semen (FAS) 0.52 dapat dilihat pada tabel 3 berikut ini:

Tabel 3. Komposisi bahan campuran beton normal

\begin{tabular}{|l|c|c|}
\hline $\begin{array}{c}\text { Bahan } \\
\text { Beton }\end{array}$ & $\begin{array}{c}\text { Berat Beton } \\
\left(\mathbf{K g} / \mathbf{m}^{3}\right)\end{array}$ & $\begin{array}{c}\text { Rasio Terhadap } \\
\text { Jumlah Semen }\end{array}$ \\
\hline \hline Air Tawar & 229 & 0,6 \\
\hline Semen & 413 & 1 \\
\hline Pasir & 530 & 1,3 \\
\hline Batu Pecah & 1058 & 2,6 \\
\hline
\end{tabular}

Sumber: Hasil Laboratorium Teknik Sipil Universitas Muhammadiyah Makassar

\section{Hasil Uji Degradasi Fisik Beton Normal Pasca Bakar}

Setelah penelitian ini dianalisis maka didapatkan hasil uji degradasi fisik beton normal pasca bakar ditinjau dari segi berat isi beton rata-rata yaitu:

1. Suhu normal $=0,002331 \mathrm{~kg} / \mathrm{cm} 3$

2. Suhu $100^{\circ} \mathrm{C}=0,002259 \mathrm{~kg} / \mathrm{cm} 3$

3. Suhu $300^{\circ} \mathrm{C}=0,002203 \mathrm{~kg} / \mathrm{cm} 3$

4. Suhu $600^{\circ} \mathrm{C}=0,002182 \mathrm{~kg} / \mathrm{cm} 3$

Sehingga dapat kita buktikan bahwa beton normal yg dibakar pada suhu $100^{\circ} \mathrm{C}$ kemudian ditingkatkan lagi suhunya menjadi $300^{\circ} \mathrm{C}$ dan kemudian ditingkatkan lagi suhunya menjadi $600^{\circ} \mathrm{C}$ terjadi penurunan berat isi beton normal, dalam hal ini terjadi degradasi fisik beton normal akibat pasca bakar, dapat kita lihat pada gambar grafik 1 berikut: 
Grafik 1. Hasil berat isi rata-rata beton pasca bakar

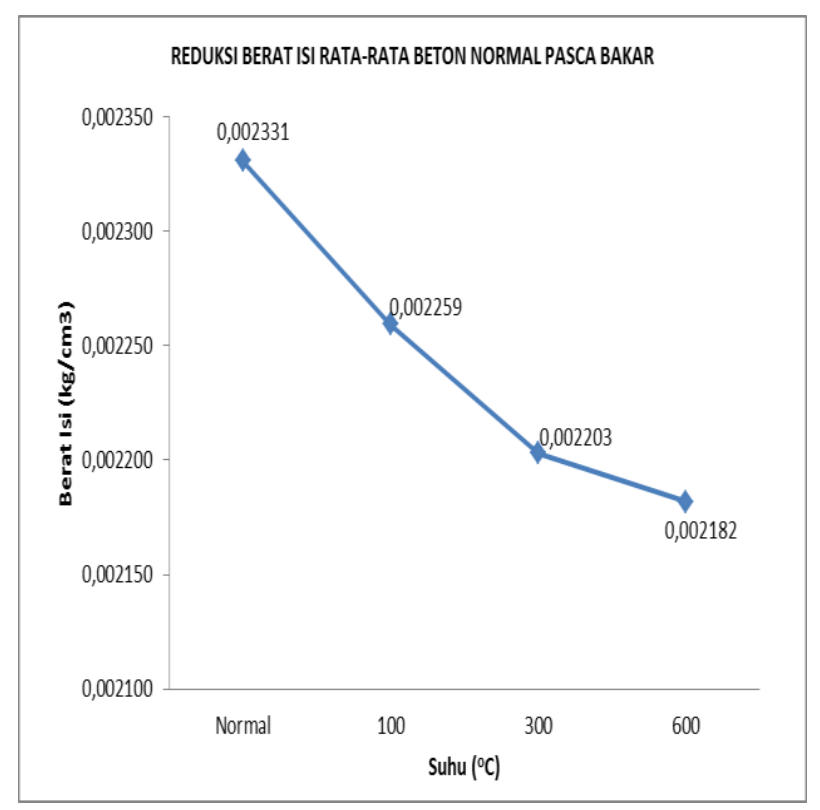

\section{KESIMPULAN DAN SARAN Kesimpulan}

Berdasarkan hasil dan pembahasan penelitian eksperimental laboratorium ini, diperoleh hasil bahwa beton normal terjadi degradasi fisik akibat pasca bakar. Degradasi fisik yang diteliti yaitu berat isi rata-rata beton normal pasca bakar terdiri dari kondisi suhu normal sebesar $0,002331 \mathrm{~kg} / \mathrm{cm} 3$, suhu $100^{\circ} \mathrm{C}$ sebesar 0,002259 $\mathrm{kg} / \mathrm{cm} 3$, suhu $300^{\circ} \mathrm{C}$ sebesar $0,002203 \mathrm{~kg} / \mathrm{cm} 3$, suhu $600^{\circ} \mathrm{C}$ sebesar $0,002182 \mathrm{~kg} / \mathrm{cm} 3$.

\section{Saran}

1. Perlu dikaji lebih lanjut mengenai degradasi fisik beton akibat pasca bakar berupa porositas beton

2. Perlu dikaji lebih lanjut mengenai degradasi fisik beton akibat pasca bakar lainnya berupa uji belah dan modulus elastisitas

\section{Ucapan Terima Kasih}

Puji Syukur Kehadirat Allah SWT, atas limpahan Rahmat dan Karunia-Nya sehingga penulisan hasil penelitian ini dapat di selesaikan.

Banyak kendala yang di hadapi oleh penulis dalam rangka penyusunan penelitian ini hingga dapat diselesaikan. Dalam kesempatan penulis dengan tulus menyampaikan terima kasih kepada Bapak Rektor Universitas Muhammadiyah Makassar, Dekan Fakultas Teknik Universitas Muhammadiyah Makassar dan Ketua dan Sekretaris Lembaga Penelitian Pengembangan dan Pengabdian Kepada Masyarakat Universitas Muhammadiyah Makassar atas bantuan dan bimbingan yang telah diberikan mulai dari penyusunan proposal hingga selesainya penulisan laporan akhir penelitian ini.

Terima kasih juga penulis sampaikan kepada Kepala Laboratorium Fakultas Teknik Universitas Muhammadiyah Makassar, dosen, karyawan dan mahasiswa dalam lingkungan Fakultas Teknik Universitas Muhammadiyah Makassar yang telah membantu penulis selama penelitian sampai pada laporan akhir penulisan penelitian ini.

Semoga bermanfaat bagi kita semua. Amin !!!

Jazakumulahu Khaeran Katsira.

\section{DAFTAR PUSTAKA}

Ahmad, I.A., 2001, Tinjauan Kelayakan Balok Beton Bertulang Pascabakar Secara Analisis dan Eksperimen, Yogyakarta: Tesis, Program Pasca Sarjana Universitas Gadjah Mada.

Ahmad, I.A. dan Taufieq, N.A.S., 2006, Tinjauan Kelayakan Forensic Engineering Dalam Menganalisis Kekuatan Sisa Bangunan Pasca Kebakaran, Makassar: Laporan Penelitian Dosen Muda. Jurusan Sipil dan Perencanaan Fakultas Teknik Universitas Negeri Makassar,

Mulyono, T., 2006, Teknologi Beton, Yogyakarta: Penerbit Andi.

Murdock, L.J. dan Brook, K.M., 2003, Bahan dan Praktek Beton, Jakarta: Cetakan Ketiga, Erlangga.

PBI, 1971, Peraturan Beton Bertulang Indonesia 1971 N.I.-2, Cetakan ke-7, Bandung: Departemen Pekerjaan Umum dan Tenaga Listrik Direktorat Jenderal Ciptakarya Direktorat Penyelidikan Masalah Bangunan.

Rahmah, S.N., 2000, Analisis Material Beton Pasca Bakar (Tinjauan Sifat Mekanik dan Kimiawi), Yogyakarta: Tesis, Program Pasca Sarjana Universitas Gadjah Mada.

Sagel, R., Kole, P. dan Kusuma. G., 1994, Pedoman Pengerjaan Beton Berdasarkan SKSNI T-151991-03, Jakarta: Cetakan Keempat, Erlangga.

Kardiono Tjokrodimulyo, 2000, Pengujian Mekanik Laboratorium Beton Pasca Bakar, Yogyakarta: Nafri.

Sirait, 2009, Kajian Perilaku Beton Bertulang Pasca Bakar,

Studi Penelitian, diakses Pada 25 juli 2009, http://bppft.brawijaya.ac.id/?hlm=bpenelitian\&view =full\&thnid=2005\&pid=1153962006

Sumardi, P.C., 2000, Aspek Kimia Beton Pasca Bakar, Yogyakarta: Kursus Singkat Evaluasi dan Penanganan Struktur Beton yang Rusak Akibat Kebakaran dan Gempa, 24-25 Maret.

Zacoeb, A. dan Anggraini, R., 2005, Kuat Tekan Beton Pasca Bakar, diakses pada 31 juli 2009, $\underline{\mathrm{htt}}$ $\mathrm{p}: / / \mathrm{b} p \mathrm{pft}$. braw i jay a a c.id/? hlm=bpenelitian \&view=full\&thnid $=2005 \&$ pid $=115$ 3962006. 